\title{
Efficiency of conventional versus Islamic banks: evidence from the Middle East
}

\begin{abstract}
Purpose: This paper aims to investigate the differences in mean cost, revenue and profit efficiency scores of conventional versus Islamic banks. It also aims to examine the effect of size and age on cost, revenue and profit efficiency of the sampled banks.

Design/methodology/approach: This study evaluates a cross-country level data compiled from the financial statements of 40 banks in 11 Organisation of Islamic Conference (OIC) countries over the period 1990-2005. The data were collected for each year available from the BankScope database. The DEA nonparametric efficiency approach originally developed by Farrell was applied to analyse the data.

Findings: The findings suggest no significant differences between the overall efficiency of conventional and Islamic banks. However, it was noted that, on average, banks are more efficient in using their resources compared to their ability to generate revenues and profits. The average bank lost an opportunity to receive 27.9 percent more revenue, given the same amount of resources. Similarly, the average bank lost the opportunity to make 20.9 percent more profits utilising the same level of inputs. Clearly there is substantial room for improvement in cost minimisation and revenue and profit maximisation in both banking systems. The size and age factor did not significantly influence the efficiency scores in both banking streams.

Originality/value: This research is substantially different from the prior work in this area in three main ways. First, it investigates cost, revenue, and profit efficiency, whereas previous studies focus on cost, profit, or cost and profit efficiency. Also, no previous studies have compared conventional and Islamic banks. Second, this study distinguishes differences among big versus small, and old versus new banks, which allows more detailed insights on the efficiency issue. Third, the age issue in Islamic banks has been addressed, so far undocumented.
\end{abstract}

Keyword: Islam; Banking; Middle East 